\title{
Population Dynamics of Brinjal Fruit and Shoot Borer, Leucinodes orbonalis Guen. and Hadda Beetle, Epilachna vigintioctopunctata Fab. on Brinjal at Allahabad Agroclimatic Region
}

\author{
Jai Hind Sharma and Anoorag R. Tayde* \\ Department of Entomology, Naini Agricultural Institute, Sam Higginbottom University of \\ Agriculture, Technology and Sciences, Allahabad - 211007, India \\ *Corresponding author
}

A B S T R A C T

\section{Keywords \\ Brinjal, Epilachna vigintioctopunctata, \\ Leucinodes \\ orbonalis, Seasonal incidence. \\ Article Info \\ Accepted: \\ 23 May 2017 \\ Available Online: \\ 10 June 2017}

The seasonal incidence of Leucinodes orbonalis Guen. (BSFB) and Epilachna vigintioctopunctata Fab. (Hadda beetle) on brinjal was studied at research farm of the Department of Entomology, Naini Agricultural institute, SHUATS, Allahabad during kharif season of 2016. Initial incidence of the BSFB was noticed on the $34^{\text {th }}$ (second last week of August) standard week and reached the peak in the $41^{\text {th }}$ (second week of November) standard week. BSFB incidence showed significant positive correlation with minimum temperature and was positively correlated with maximum temperature, morning relative humidity, rainfall and wind velocity. Whereas Hadda beetle population was noticed on $30^{\text {th }}$ (last week of July) standard week and reached to peak in the $35^{\text {th }}$ (last week of August) standard week. Hadda beetle incidence showed significant negative correlation with morning relative humidity and significant positive correlation with sunshine.

\section{Introduction}

Botanically brinjal is known as Solanum melongena $L$. $(2 \mathrm{n}=24)$ popularly known as eggplant belongs to family Solanaceae and India is its center of origin and diversity. Brinjal is one of the most commonly grown vegetable crops of the country. India produces about 7.67 MT of brinjal from an area of 0.47 $\mathrm{M}$ ha with an average productivity of 16.30 $\mathrm{Mt} / \mathrm{ha}$. The brinjal producing states are Odisha, Bihar, Karnataka, West Bengal, Andhra Pradesh, Maharashtra and Uttar Pradesh. Brinjal has ayurvedic medicinal properties and white brinjal is good for diabetic patients. It is also a source of vitamins $\mathrm{A}, \mathrm{C}$ and minerals (Source:
NCPAH). The brinjal crop is attacked by about 140 species of insect pests (Dwivedi et al., 2014). BSFB, L. orbonalis (Lepidopetra: Pyralidae) is the key pest throughout Asia (Purohit and Khatri, 1973; Kuppuswamy and Balasubramanian, 1980; Allam et al., 2003). In India, this pest has a countrywide distribution and has been categorized as the most destructive and most serious pest causing huge losses in brinjal (Patil, 1990).

Leucinodes orbonalis Guenee (Lepidoptera: Pyraustidae), causes significant losses to the tune of $70 \%$ (Sandanayake and Edirisinghe, 1992). Due to its fast reproductive potential, 
quick turn over of generation and most common cultivation of brinjal in both wet and dry season, this pest poses a serious threat. In early stages of the crop growth, larvae of brinjal BSFB, L. orbonalis, bores into the shoots resulting in dropping, withering and drying if the affected shoots. During the reproductive stage, tiny larvae bore into the flower buds and fruits, the bored holes are invariably plugged with excreta. The infested fruits become unfit of consumption due to loss of quality and lose their market value. In India, damage levels of pest have been noticed in different regions resulting considerable damage to the fruits. It is generally severe in the July transplanted crop and estimated economic injury level to $6 \%$ infestation (AVRDC, 2003).

Next to BSFB, the Hadda beetle Epilachna vigintiopunctata Fab. (Coleoptera: Coccinellidae) is one of the most important destructive pest and cause considerable economic losses to many crop including brinjal (Bhagat and Munshi, 2004; Islam et al., 2011) and to a number of solanaceous, cucurbitaceous and leguminous crop extensively found all over India and in other countries (Anam et al., 2006; Rahaman et al., 2009). It is highly destructive at both, adult and larval stages, which feed on the epidermal tissue of leaves, flower and fruits by scraping the chlorophyll content and cause a big yield loss (Ghosh and Senapati, 2001). The effected leaves of the plant become skeletonized, gradually dry and drop down. The grubs confine their attack to the lower surface while adult beetles usually feed on upper surface.

Several biotic and abiotic factors contribute in lowering the yield in brinjal. Among various biotic factors, insect pests are important which greatly affect the quality and productivity of brinjal crop through inflicting a direct damage.
The variability in their population and damage can be related to changes in the ambient environment. With a view on the climate change projections for India, an attempt has been made here to study the impact of the likely changes in abiotic component in relation to BSFB and Hadda beetle in brinjal crop under Allahabad agroclimatic conditions.

\section{Materials and Methods}

The study on population dynamics of $L$. orbonalis Guen. And E. vigintioctopunctata Fab. Was carried out at the research farm of the Department of Entomology, Naini Agricultural institute, SHUATS, Allahabad during kharif season of 2016. On brinjal variety Banaras round, a popular variety among farmers of Allahabad region, during the kharif of 2016. In this experiment, plants were planted at a spacing $60 \times 45 \mathrm{~cm}$ on plot size $5 \times 3 \mathrm{~m}^{2}$ area with 3 replications. No pesticide was used throughout the experiment. Population of BSFB larvae and Hadda beetle during the experimental period i.e. 29th standard week (Third week of July) to $45^{\text {th }}$ standard week (Second week of November, 2016) was recorded on these untreated experimental plots (Table 1). The observations on population of BSFB and Hadda beetle were taken regularly at 7 days interval till the completion of this experiment. Population of BSFB larvae was first observed on brinjal shoots in the $34^{\text {th }}$ standard week (third week of August, 2016) and that of Hadda beetle in the $30^{\text {th }}$ standard week (fourth week of July). As fruit bearing initiated, these larvae (BSFB) were observed migrating to developing fruits. The damaged fruits were harvested and carefully cut opened with a sharp knife to observe the presence of larvae in the fruits. Weekly meteorological data throughout the experimental period was procured from the Meteorological Department, SHUATS. 


\section{Results and Discussion}

The occurrence of shoot and fruit borer, Leucinodus orbonalis Guen.in 2016 Kharif season was commenced from $34^{\text {th }}$ standard week with an average 0.64BSFB infestation. The shoot and fruit borer population increased and gradually reached peak level of 5.21BSFB infestation at $41^{\text {st }}$ standard week. However no infestation was observer on $46^{\text {th }}$ standard week. As the temperature declined, the population of BSFR also declined till the end of November, 2016. The BSFB population was significant and positively correlated $(\mathrm{r}=0.503)$ with minimum temperature $\left({ }^{0} \mathrm{C}\right)$. Larval population was also positively correlated with maximum temperature, Humidity \% morning, Rainfall ( $\mathrm{mm}$ ), and Wind velocity but proved to be non-significant. Earlier reports also suggest that maximum and minimum temperature and abundance of brinjal shoot and fruit borer showed a positive correlation (Shukla and Khatri, 2010). Correlation of brinjal shoot and fruit borer infestation with maximum temperature and also with relative humidity was observed but was found to be nonsignificant (Shyamprasad and Logiswaran, 1997). Many of the earlier workers have also reported the incidence of shoot and fruit borer throughout the year in different regions of South East Asia (Khan and Al-salem, 2007 and Mall et al., 1992). Our present studies are in great accordance with (Katiyar and Mukharji 1974) who reported the highest damage of 90 per cent in the month of November (Table 2).

The occurrence of Hadda beetle, Epilachna vigintioctopunctata Fab. In 2016 kharif season was commenced from $30^{\text {th }}$ standard week with an average 1.2 Hadda beetle per plants. Hadda beetle population increased and gradually reached to the peak level of 3.6 at $35^{\text {th }}$ standard week. However no Hadda beetle was observed on $41^{\text {th }}$ standard week. Hadda beetle population was significant with Humidity \% morning and Sunshine (hr/day) but proved to be negatively (-0.642) and positively (0.781) correlated respectively.

Table.1 Seasonal incidence of BSFB and HADDA BEETLE during Kharif 2016

\begin{tabular}{|c|c|c|c|c|c|c|c|c|c|}
\hline \multirow{2}{*}{$\begin{array}{c}\text { Standard } \\
\text { week }\end{array}$} & \multirow{2}{*}{ BSFB } & \multirow{2}{*}{$\begin{array}{c}\text { Hadda } \\
\text { beetle }\end{array}$} & \multicolumn{2}{|c|}{ Temperature } & \multicolumn{2}{|c|}{ Humidity \% } & Rainfall & $\begin{array}{c}\text { Wind } \\
\text { Velocity }\end{array}$ & $\begin{array}{c}\text { Sunshine } \\
\text { (hr/day) }\end{array}$ \\
\hline $29^{\text {th }}$ & 00.00 & 00.00 & 32.7 & 27.67 & 92.14 & 65.85 & 06.28 & 01.59 & 04.42 \\
\hline $30^{\text {th }}$ & 00.00 & 01.20 & 33.68 & 24.22 & 90.42 & 63.71 & 01.11 & 02.00 & 03.82 \\
\hline $31^{\text {st }}$ & 00.00 & 01.90 & 35.34 & 28.02 & 90.71 & 58.71 & 00.42 & 02.77 & 05.45 \\
\hline $32^{\text {nd }}$ & 00.00 & 02.30 & 34.08 & 27.74 & 90.57 & 55.42 & 02.20 & 01.33 & 05.82 \\
\hline $33^{\text {rd }}$ & 00.00 & 02.60 & 35.97 & 27.51 & 92.42 & 53.42 & 05.00 & 01.28 & 05.34 \\
\hline $34^{\text {th }}$ & 00.64 & 03.40 & 33.22 & 27.00 & 92.85 & 58.28 & 12.48 & 02.22 & 04.80 \\
\hline $35^{\text {th }}$ & 01.42 & 03.60 & 35.82 & 27.28 & 90.57 & 53.42 & 06.94 & 00.25 & 05.07 \\
\hline $36^{\text {th }}$ & 02.48 & 02.90 & 35.14 & 27.20 & 87.85 & 53.85 & 00.65 & 02.26 & 08.08 \\
\hline $37^{\text {th }}$ & 03.31 & 02.30 & 35.25 & 27.28 & 89.42 & 54.28 & 04.91 & 01.26 & 08.34 \\
\hline $38^{\text {th }}$ & 03.92 & 01.00 & 33.28 & 26.87 & 89.14 & 62.57 & 01.14 & 00.87 & 06.62 \\
\hline $39^{\text {th }}$ & 04.24 & 00.60 & 30.25 & 26.22 & 89.42 & 66.28 & 08.08 & 00.66 & 05.28 \\
\hline $40^{\text {th }}$ & 05.12 & 00.20 & 34.65 & 26.68 & 87.42 & 53.85 & 06.37 & 02.22 & 07.45 \\
\hline $41^{\text {st }}$ & 05.21 & 00.00 & 34.48 & 26.34 & 89.85 & 52.28 & 01.42 & 01.01 & 08.52 \\
\hline $42^{\text {nd }}$ & 04.88 & 00.00 & 35.05 & 25.77 & 89.71 & 51.71 & 00.00 & 00.81 & 08.77 \\
\hline $43^{\text {rd }}$ & 04.31 & 00.00 & 34.37 & 24.8 & 90.28 & 53.71 & 00.00 & 01.01 & 08.75 \\
\hline $44^{\text {th }}$ & 03.64 & 00.00 & 33.97 & 19.82 & 90.71 & 54.42 & 00.00 & 01.08 & 08.57 \\
\hline $45^{\text {th }}$ & 02.26 & 00.00 & 33.14 & 18.2 & 91.85 & 55.71 & 00.00 & 01.02 & 06.91 \\
\hline
\end{tabular}


Table. 2 Correlation between BSFB and HADDA BEETLE and Weather parameter during Kharif 2016

\begin{tabular}{|c|c|c|c|c|c|c|}
\hline & \multicolumn{3}{|c|}{ L. orbonalis } & \multicolumn{3}{c|}{ E. vigintioctopunctata } \\
\cline { 2 - 7 } & r value & t value & F -test & r value & t value & F -test \\
\hline Temp. Max. $\left.{ }^{\mathbf{0}} \mathbf{C}\right)$ & 00.392 & 01.649 & NS & -00.110 & -00.430 & NS \\
\hline Temp. Min. $\left({ }^{0} \mathbf{C}\right)$ & 00.503 & 02.255 & S & -00.210 & -00.834 & NS \\
\hline Humidity Morning\% & 00.159 & 00.625 & NS & -00.642 & -03.244 & S \\
\hline Humidity Evening\% & -00.128 & -00.500 & NS & -00.315 & -01.285 & NS \\
\hline Rainfall(mm) & 00.438 & 01.885 & NS & -00.204 & -00.808 & NS \\
\hline Wind velocity & 00.211 & 00.838 & NS & -00.392 & -01.648 & NS \\
\hline Sunshine(hr/day) & -00.395 & -01.666 & NS & 00.781 & 04.836 & S \\
\hline
\end{tabular}

Fig.1 Seasonal incidence of BSFB and HADDA BEETLE during Kharif 2016

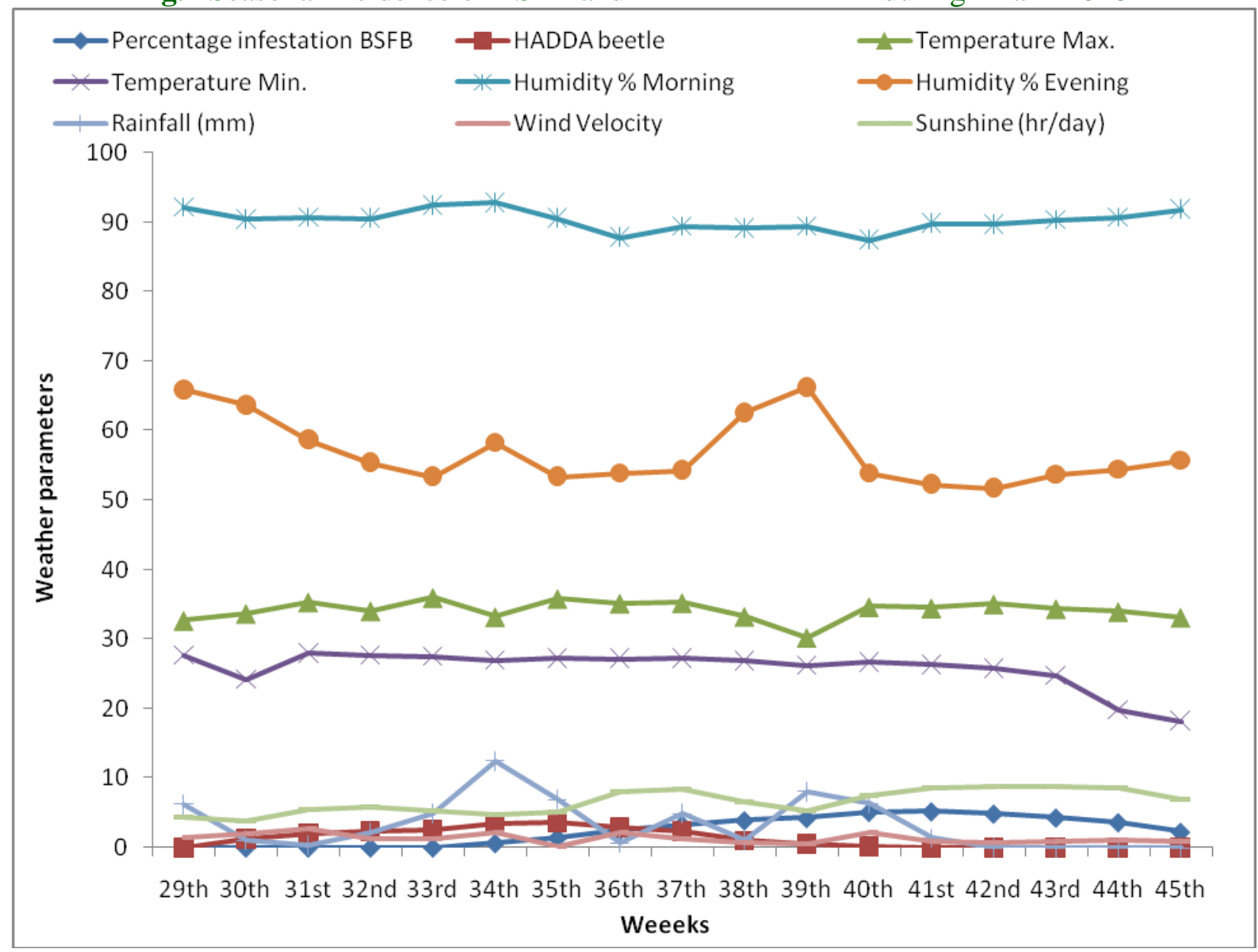

The present findings correlates with the finding of Manjoo and Swaminathan (2007), who under Udaipur condition found maximum population of pest on ashwagandha during October, which gradually decreased and reached to zero level in December. (Khursheed and Desh, 2014), found the total peak population (grubs, pupae and adults) of
36.9 and 59.7 insects per plant was recorded during 3rd and 4th week of August (33 and 34 SW) in 2009 and 2010,respectively and was negatively correlated with temperature.

The present experiment provides a basic study for seasonal incidence (Fig. 1). It can be concluded that seasonal population 
fluctuation of major insect pests on brinjal crop is greatly influenced by abiotic factors and peak population levels are observed during (Kharif) August - November. The statistically significant values indicated that occurrence of insect pests population was due to the prevailing ecological conditions. The management of brinjal pest during kharif sown brinjal under semi-tropical agroclimatic zone should therefore be promoted and tailored from august onwards using an integrated approach.

\section{References}

Alam, S.N., Rashid, M.A., Rouf, F.M.A., Jhala, R.C., Patel, J.R., Satpathy, S., Shivalingaswamy, T.M., Wahundeniya, S., Cork, A., Ammaranan, C. and Talekar, N.S. 2003. Development of an integrated pest management strategy for eggplant fruit and shoot borer in South Asia. Technical Bulletin No. 28. AVRDC Publication Number 03-548. AVRDC-The World Vegetable Centre, Shanhua, Taiwan. 56p.

Anam, M., Ahmad, M. and Haque, M. A. 2006. Efficacy of neem oil on the biology and food consumption of epilachna beetle, Epilachna dodecastigma (Weid.). Journal of Agriculture and Rural Development, 4(1and2): 83-88.

AVRDC. 2003. Development of an IPM strategy for eggplant fruit and shoot borer in south Asia. Technical bulletin. 28:1-23.

Bahaduri, P.N., 1951. Indian J. Gen., 11: 7582.

Bhagat, K.C. and Munshi, S.K. 2004. Host preference of spotted leaf eating beetle, Henosepilachna vigintioctopunctata (Fabr.) on different brinjal varieties. Pest Management and Economic Zoology, 12, 77-81.

Dwivedi, R.K., Tripathi, A., Pal, R.K. and
Singh, D.K. 2014. Effect and ecofriendly management of $B S F B$ (Leucinodes orbonalis Guenee) on brinjal. Int. J. Plant Prot., 7: 287-291.

Ghosh, Sunilkumar and Senapati, S.K. 2001. Evaluation of brinjal varieties commonly grown in Terai region of West Bengal against pest complex. Crop research. 21(2): 157-163.

Gupta, H. C. L., Mehta, S. C. and Pareek, B. L. 1987. Bioefficiency and residue of carbaryl investigation in/on brinjal. Veg. Sci. 14(2): 185-194.

Islam, M. N. and Karim, M. A. 1991. Management of the brinjal shoot and fruit borer, Leucinodes orbonalis Guenee (Lepidoptera: Pyralidae) in field. In: Annual Research Report. Entomology Division, Bangladesh Agric. Res. Inst. Joydabpur, Gazipur. 44-46.

Khan, A. and Al-salem, S. 2007. Seasonal variation effect on air borne pollutants. J. Environ. Res. Develop. 1(3): 215-218.

Khursheed, S. and Raj, D. 2014. Population Dynamics of Hadda Beetle, Henosepilachna vigintioctopunctata on Bittergourd in Mid-hill Himalayas. Indian J. of Plant Protec. 42(1): 59-63.

Kuppuswamy, S. and Balasubramanian, M. 1980. Efficacy of synthetic pyrethroids against brinjal fruit borer Leucinodes orbonalis Guen. South Indian Hort., 28: 91-93).

Mall N. P., Pandey R. S., Singh S. V. and Singh S. K. 1992. Seasonal incidence of insect pests and estimation of the losses caused by shoot and fruit borer on brinjal. Indian J. Entomol. 63(2): 137143.

Manjoo, S. and Swaminathan, R. 2007. Bioecology and management of Henosepilachna vigintioctopunctata (Fabricius) (Coleoptera: Coccinellidae) infesting ashwagandha [Withania somnifera (L.) Dunal]. J. Med. Aromat. 
Plants, 29: 16-19.

National Committee on Plasticulture Application in Horticulture (NCPAH). http://www.ncpahindia.com/brinjal.php.

Patil, P.D. (1990). Technique for mass rearing of the rearing of the brinjal shoot and fruit borer, Leucinodes orbonalis Guen. J. Entomol. Res., 14: 164-172.

Purohit, M.L. and Khatri, A.K. 1973. Note on the chemical control of Leucinodes orbonalis Guen. (Lepidopetra: Pyralidae) on brinjal. Indian J. Agric. Sci., 43: 214-215.

Rahman, M.M., Ali, M.R. and Hossain, M.S. 2009. Evaluation of combined management options for managing brinjal shoot and fruit borer. Academic
J. Entomol., 2(2): 92- 98.

Sandanayake, W. R. M. and Edirisinghe, J. P. 1992. Trathala flavoorbitalis: parasitization and development in relation to host stage attacked. Insect Science and Its Application. 13(3): 287292.

Shukla, A. and Khatri S. N. 2010. Incidence and abundance of brinjal shoot and fruit borer Leucinodes orbonalis Guenee. The Bioscan. 5(2): 305-308.

Shyamprasad, G. and Logiswaran, G. 1997. Influence of weather factors on population fluctuation of insect pests on brinjal at Madurai, Tamil Nadu. Indian J. Entomol., 59(4): 385-388.

\section{How to cite this article:}

Jai Hind Sharma and Anoorag R. Tayde. 2017. Population Dynamics of Brinjal Fruit and Shoot Borer, Leucinodes orbonalis Guen. and Hadda Beetle, Epilachna vigintioctopunctata Fab. on Brinjal at Allahabad Agroclimatic Region. Int.J.Curr.Microbiol.App.Sci. 6(6): 2055-2060. doi: https://doi.org/10.20546/ijcmas.2017.606.243 